\title{
The Politics of Influence: Recognizing Influence Dilution Claims under $\$ 2$ of the Voting Rights Act
}

\author{
Stanley Pierre-Louis $\dagger$
}

Following each census, local officials redraw electoral district boundaries according to shifts in population. The Voting Rights Act of 1965 ("VRA") often requires these newly drawn districts to demonstrate sensitivity to minority voter areas in which discrimination has previously occurred. If a newly devised reapportionment scheme dilutes minority voting strength, minority voters may contest the plan under $\S 2$ of the VRA. ${ }^{1}$ In a typical vote dilution claim, plaintiffs challenge a reapportionment plan that hinders the creation of a majority-minority district-a singlemember district in which a minority group accounts for more than 50 percent of the population. ${ }^{2}$ In Thornburg $v$ Gingles, the United States Supreme Court held that such claims fell within the scope of $\S 2$ only if the group of minority plaintiffs is sufficiently large and geographically compact to constitute a majority in a single-member district, demonstrates political cohesiveness, and successfully establishes that white voters have discriminatorily blocked it from electing the minority-preferred candidate. $^{3}$

Despite the cognizability of vote dilution claims by "sufficiently large" minority groups seeking to form majority-minority districts, whether a small group of minority voters can state a vote dilution claim under $\S 2$ remains highly disputed. Although a small group of minority voters might lack the numerical strength to compose a majority-minority district, the group might

$\dagger$ B.A. 1992, Clark University; J.D. 1995, The University of Chicago.

1 Voting Rights Act of $1965 \S 2$, Pub L No 89-110, 79 Stat 437 (1965), codified as amended at 42 USC § 1973(a) (1988).

${ }^{2}$ See, for example, Thornburg $v$ Gingles, 478 US 30, 35, $46-48$ (1986). A singlemember district elects one candidate to office; a multimember, or at-large, district elects several candidates to office.

${ }^{3}$ Id at 50-51. When plaintiffs can demonstrate intentional discrimination in the drawing of district lines, they might also have a constitutional claim under the Equal Protection Clause of the Fourteenth Amendment. See Garza v County of Los Angeles, 918 F2d 763, 766, 771 (9th Cir 1990). 
nonetheless possess sufficient numbers to influence the tenor or outcome of an election. Vote dilution claims challenging singlemember districting schemes that split a small group of minority voters to dilute their influence in any particular district are called "influence" claims, ${ }^{4}$ or "influence dilution" claims. Neither the Supreme Court nor Congress has explicitly indicated whether influence dilution claims warrant $\S 2$ protection. Lower courts facing the issue have either recognized or rejected such claims, depending on their reading of the Gingles opinion.

Section I of this Comment examines the current law interpreting the VRA and the present status of influence dilution claims. Section II critiques lower courts that have held that the Gingles test applies to influence dilution claims. Section III argues that "influence districts," the remedy sought under influence dilution claims, are legitimate means to carry out the goals of the VRA. It contends that strengthening small minority voting blocs encourages candidates' responsiveness to minority interests, fosters interracial coalitions, and avoids racial divisiveness. Finally, Section IV proposes a standard for determining when influence dilution claims warrant $\S 2$ protection. Under this proposed test, courts will be able to distinguish between valid and more "marginal" influence dilution claims by assessing three crucial factors: the minority plaintiffs' political cohesiveness; the geographic compactness of the proposed influence district; and the potential for interracial coalitions, crossover voting, and a minority swing vote.

\section{THE VRA AND JUDICIAL INTERPRETATION}

\section{A. The VRA and Its History}

Congress passed the Voting Rights Act of 1965 to protect the voting rights of African Americans. ${ }^{5}$ Discrimination against African Americans was particularly rampant in the South, where

- Jack Quinn, Jonathon B. Sallet, and Donald J. Simon, Congressional Redistricting in the 1990s: The Impact of the 1982 Amendments to the Voting Rights Act, 1 Geo Mason U Civ Rts L J 207, 223-34 (1990). Influence claims are also known as "ability to influence" claims.

${ }^{5}$ See generally Katherine I. Butler, Constitutional and Statutory Challenges to Election Structures: Dilution and the Value of the Right to Vote, $42 \mathrm{La}$ L Rev 851, 853 (1982). The Voting Rights Act has been interpreted to protect all racial, ethnic, and language minority groups. For example, in White $v$ Regester, 412 US 755, 765-70 (1973), the Supreme Court upheld a constitutional challenge under $\S 2$ brought by African Americans and Mexican-Americans to parts of a legislative reapportionment scheme in Texas. See also Campos v City of Baytown, Texas, 840 F2d 1240, 1250 (1988). 
restrictions on registering and balloting, such as literacy tests, white primaries, poll taxes, and grandfather clauses, deprived African Americans of their right to vote by systematically denying them access to and participation in the electoral process. ${ }^{6}$ The VRA also sought to prevent the further dilution of African American votes in both majority white districts and areas where African Americans could constitute the majority of a district. ${ }^{7}$

Congress later amended $\S 2$ of the VRA to counteract minority vote dilution schemes that lead to discriminatory "results." The amendment to $\S 2$ overturned the Supreme Court's plurality in City of Mobile $v$ Bolden, ${ }^{9}$ in which the Court found that black voters challenging an at-large scheme must demonstrate that the underlying districting scheme stems from some discriminatory intent, not merely that the scheme produced a discriminatory result. After the amendment to $\S 2$, plaintiffs need only show discriminatory results of election practices to challenge an at-large district scheme. ${ }^{10}$

6 White, 412 US at 766-67. See also William N. Eskridge, Jr. and Philip P. Frickey, Cases and Materials on Legislation, Statutes and the Creation of Public Policy 127, 146-47 (West, 2d ed 1995). To prevent circumvention of the VRA by other discriminatory measures, Congress enacted $\S 5$, which requires either the Attorney General or the United States District Court for the District of Columbia to determine whether changes in voting qualifications or procedures served to discriminate against minority voters. Voting Rights Act of $1965 \S 5$, Pub L No 89-110, 79 Stat 437,439 , codified as amended at 42 USC $\S$ $1973 \mathrm{c}$ (1988). This so-called "preclearance requirement" did not apply nationwide; rather, it was designed to cover the Deep South, where the worst instances of voter discrimination had occurred. Congress intended the preclearance requirement to lapse in five years. However, the Act was renewed for five years in 1970 and for seven more years in 1975. In 1982, Congress amended the Act to terminate its coverage in twenty-five years. Eskridge and Frickey, Cases and Materials on Legislation at 147. As a final tool of enforcement, Congress enacted 28 USC $\$ 2284(a)$, which mandates that a three-judge panel hears voting rights cases. Act of August 12, 1976 §, Pub L No 94-381, 90 Stat 1119.

7 Methods of vote dilution and electoral manipulation include "stacking," "cracking," and "packing." "Stacking" entails at-large elections or multimember districting that tend to prevent minorities from winning. In "cracking," or fragmenting, white legislatures quarter off concentrated minority voters into predominantly white districts to minimize the strength of minority voters in any given district. "Packing" is achieved by compacting minority groups into very few districts in order to limit minority representation. See Eskridge and Frickey, Cases and Materials on Legislation at 127.

8 Id at 149. Discriminatory "results" refers to the systematic failure of minority candidates to be elected because of opposition by white voters, regardless of white voters' intent.

9446 US 55 (1980).

10 As amended, 42 USC § 1973(a)-(b) (1988) reads:

(a) No voting qualification or prerequisite to voting or standard, practice, or procedure shall be imposed or applied by any State or political subdivision in a manner which results in a denial or abridgement of the right of any citizen of the United States to vote on account of race or color ... as provided in subsection (b) of this section. 
Congress has indicated that courts must look at the "totality of the circumstances" to determine whether particular election practices have caused discriminatory results. ${ }^{11}$ Section 2 of the VRA explicitly provides that minority groups have no "right to have members of a protected class elected in numbers equal to their proportion in the population." ${ }^{12}$ Accordingly, courts cannot find vote dilution based simply on the denial of proportional representation for minority groups. Instead, the Senate Report accompanying $\S 2$ contains various factors courts should consider when determining whether vote dilution has occurred. ${ }^{13}$ This

(b) A violation of subsection (a) of this section is established if, based on the totality of circumstances, it is shown that the political processes leading to nomination or election in the State or political subdivision are not equally open to participation by members of a class of citizens protected by subsection (a) of this section in that its members have less opportunity than other members of the electorate to participate in the political process and to elect representatives of their choice. The extent to which members of a protected class have been elected to office in the State or political subdivision is one circumstance which may be considered: Provided, That nothing in this section establishes a right to have members of a protected class elected in numbers equal to their proportion in the population.

1142 USC $\S 1973(\mathrm{~b})$.

12 Id.

13 Although Senate reports ordinarily do not constitute an authoritative source, the Senate Report accompanying the Voting Rights Act has proven pivotal in judicial determinations of minority vote dilution. See Gingles, 478 US at 36-38. See also Armour v Ohio, 775 F Supp 1044, 1053-58 (N D Ohio 1991). The Senate Committee instructed courts to examine:

1. the extent of any history of official discrimination in the state or political subdivision that touched the right of the members of the minority group to register, to vote, or otherwise to participate in the democratic process;

2. the extent to which voting in the elections of the state or political subdivision is racially polarized;

3. the extent to which the state or political subdivision has used unusually large election districts, majority vote requirements, anti-single shot provisions, or other voting practices or procedures that may enhance the opportunity for discrimination against the minority group;

4. if there is a candidate slating process, whether members of the minority group have been denied access to that process;

5. the extent to which members of the minority group in the state or political subdivision bear the effects of discrimination in such areas as education, employment and health, which hinder their ability to participate effectively in the political process;

6. whether political campaigns have been characterized by overt or subtle racial appeals;

7. the extent to which members of the minority group have been elected to public office in the jurisdiction.

Additional factors that in some cases have had probative value as part of plaintiffs' evidence to establish a violation are: whether there is a significant lack of responsiveness on the part of elected officials to the particularized needs of the members of the minority group [and] whether the policy underlying the state or political subdivision's 
totality of the circumstances approach allows courts to exercise discretion to determine when a voting structure prejudicially impairs minority voting strength.

In sum, the VRA has served two related purposes. First, it has worked specifically to eradicate discriminatory practices that inhibit minority groups' ability to register and vote. Second, it has sought to curtail minority vote dilution.

B. Judicial Treatment of Influence Dilution Claims under $\S 2$ of the Voting Rights Act

1. Supreme Court jurisprudence.

Soon after passage of the $\S 2$ amendment, the Supreme Court, in Thornburg $v$ Gingles, had the opportunity to interpret the amended vote dilution provisions. ${ }^{14}$ Gingles involved a challenge to an at-large electoral scheme. The Court held that to satisfy the "results" requirement of $\S 2$ minority groups must pass a three-part threshold test before their vote dilution claims are entitled to analysis under the "totality of the circumstances" inquiry $\S 2$ requires. The group must (1) show that it is sufficiently large and geographically compact to constitute a majority in a single-member district; (2) demonstrate political cohesiveness; and (3) establish that white voters have discriminatorily blocked it from electing the minority-preferred candidate. ${ }^{15}$

Although the Supreme Court in Gingles did not adequately address the cognizability of influence dilution claims, the Court has not ruled out the possibility that $\S 2$ applies to such claims. In addressing cases in which the minority group was not "sufficiently large," the Court explicitly left a void by establishing its holding for "ability to elect" claims, but not for "ability to influence" claims. ${ }^{16}$ Courts and commentators have interpreted

use of such voting qualification, prerequisite to voting, or standard, practice or procedure is tenuous.

Voting Rights Act Amendments of 1982, S Rep No 97-417, 97th Cong, 2d Sess 28-29 (1982), reprinted in 1982 USCCAN 206-07 (citations omitted).

14 478 US 30.

15 Id at 50-51.

${ }^{16}$ The Gingles Court noted in a footnote:

We have no occasion to consider... what standards should pertain to [ ] a claim brought by a minority group, that is not sufficiently large and compact to constitute a majority in a single-member district, alleging that the use of a multimember district impairs its ability to influence elections.

Id at 46-47 $\mathrm{n} 12$. 
Gingles to imply that influence dilution claims should not necessarily be governed by exactly the same standards as vote dilution claims. ${ }^{17}$

Subsequent Supreme Court opinions have explicitly left unresolved the question of whether the Gingles test applies to such claims. In Growe $v$ Emison, the Court extended the application of the Gingles threshold factors to $\S 2$ challenges against singlemember districting plans; however, the Court expressly declined to resolve whether influence dilution claims warranted $\S 2$ protection. ${ }^{18}$ In Voinovich $v$ Quilter, the Court faced another case involving influence dilution claims. ${ }^{19}$ There, white Democrats asserted that "packing" African Americans into a few districts amounted to influence dilution, by minimizing the total number of districts in which black voters, with the help of crossover white voters, could select their candidates of choice.$^{20}$ The Court ruled, however, that the newly drawn districts, though an "ironic"1 consequence of the VRA, did not hinder African American participation in the electoral process. ${ }^{22}$ Still, the Court reserved the question of influence dilution claims for a later date. ${ }^{23}$ And in DeGrandy $v$ Johnson, the Court's most recent opportunity to explore the issue, the question also remained unanswered. ${ }^{24}$

Even though the Court only briefly mentioned "ability to influence" claims, courts and commentators alike have taken the footnote to mean that such claims may exist under the VRA. See, for example, Armour v. Ohio, 775 F Supp 1044, 1059-60 n 19 (N D Ohio 1991); Hastert v Board of Elections, 777 F Supp 634, 651 (N D Ill 1991); West $v$ Clinton, 786 F Supp 803, 806 (W D Ark 1992); Kathryn Abrams, "Raising Politics Up": Minority Political Participation and Section 2 of the Voting Rights Act, 63 NYU L Rev 449, 451-53 (1988) (arguing that the Supreme Court's focus on the electoral phase of the political process is too narrow).

${ }^{17}$ See Quinn, Sallet, and Simon, 1 Geo Mason U Civ Rts L J at 223-34 (cited in note 4) (discussing the possibility "that the Gingles standards do not by themselves bar an influence claim and that they [influence claims] must be judged by a different standard").

${ }_{18} 113$ S Ct 1075, 1084-85 n 5 (1993), citing Gingles, 478 US at 46-47 n 12 (declining to reach the issue because the district court had considered only the "ability to elect" claim).

19113 S Ct 1149 (1993).

${ }^{20}$ Id at 1153.

21 Justice Scalia used the word "ironic" during oral argument to describe the consequence of the redistricting scheme. Mary Anne Sharkey, Watershed Voting Rights Case; GOP Move to Favor Black Incumbents Put Democrats in Bind, Cleveland Plain Dealer 3A (Dec 9, 1992).

${ }^{22}$ Quilter, $113 \mathrm{~S} \mathrm{Ct}$ at 1158 (finding that appellees failed to satisfy the third Gingles precondition, namely, significant white block voting).

${ }^{23}$ Id at 1155, citing Gingles, 478 US at 46-47 nn 11-12 (declining to reach the issue).

${ }^{24} 114 \mathrm{~S} \mathrm{Ct} 2647,2656$ (1994), citing Quilter, $113 \mathrm{~S}$ Ct at 1155; Growe, $113 \mathrm{~S}$ Ct at $1084 \mathrm{n} 5$; Gingles, 478 US at 46-47 n 12 (also declining to reach the issue). 
2. Lower courts' interpretations.

Although the Supreme Court has been reluctant to determine whether $\S 2$ applies to influence dilution claims, several lower courts have squarely confronted the issue. Currently the dispute centers on whether the Gingles test should apply to such claims. Because no influence dilution claim can survive the first prong of the Gingles test-that the minority group is sufficiently large and geographically compact to constitute a majority in a single-member district-courts that apply Gingles to such claims have held that they are not covered by $\S 2$. Courts that have held that the Gingles test does not apply to influence dilution claims have held that these claims are in fact covered by $\S 2$, and proceed to examine the case under the "totality of circumstances" test of the statute.

Courts recognizing influence dilution claims deem the Gingles test inapplicable. In Armour v Ohio, for example, minority voters challenged a redistricting plan that split African American voters in the city of Youngstown, Ohio, between two predominately white suburbs. ${ }^{25}$ Black voters, formerly districted together, comprised 25 percent of newly drawn District 52 and 11 percent of newly drawn District $53 .{ }^{26}$ The Armour plaintiffs argued that this splitting of minority voters effectively and intentionally violated $\S 2$. The plaintiffs proposed an alternative plan that would place 1 percent of the minority population in District 52 and 99 percent in District 53 . The plaintiffs asserted that if minorities constituted almost one-third of the voting-age population in District 53, they would be able to voice their concerns on local issues more effectively and thus act as an influential voting bloc in the district's primary and general elections. ${ }^{27}$

The three-judge panel's majority agreed and held for the plaintiffs. The panel pointed to the Supreme Court's refusal to rule out "ability to influence" claims in Gingles to advance the notion that $\S 2$ did not bar influence dilution claims. To buttress the notion that minority groups could influence election results in district elections, the Armour court relied on Chisom v Roemer ${ }^{28}$ Since minority voters could assert considerable influence in District 53 if that District's minority population were strengthened,

25775 F Supp 1044, 1047-48 (N D Ohio 1991).

26 Id at 1047 .

27 Id at 1047-48, 1059-60.

${ }^{28}$ Id at 1052, quoting Chisom $v$ Roemer, 501 US 380, 397 n 24 (positing that a small group of voters can influence the outcome of an election). 
the Armour court concluded that the Gingles preconditions were inapplicable, and proceeded to an analysis of the "totality of circumstances."29

Conversely, courts that have not recognized influence dilution claims have imposed the Gingles test. No influence dilution claim can survive the Gingles test because its very first prong requires the minority group to show that it is sufficiently large to constitute a majority. ${ }^{30}$ In McNeil v Springfield Park District, for instance, the Seventh Circuit held that influence dilution claims must satisfy the Gingles threshold. ${ }^{31}$ The court concluded that maintaining the bright-line standard set in Gingles would advance the Supreme Court's sole concern-promoting majorityminority districts. ${ }^{32}$ It further admonished that abandoning the Gingles standard for influence dilution claims would allow "the most marginal $\S 2$ claims" to flood the judicial docket. ${ }^{33}$ It sought instead to limit the "totality of circumstances" inquiry to $\S$ 2 claims that lacked frivolity-in other words, to limit $\S 2$ actions to those that seek to create majority-minority districts. ${ }^{34}$

29775 F Supp at 1052. See also LeBlaric-Sternberg $v$ Fletcher, 781 F Supp 261 (S D NY 1991), which has been cited as recognizing influence dilution claims. There, a group of Orthodox Jews in the town of Ramapo, New York, accounting for roughly 23 percent of Ramapo's population, alleged that in incorporating Airmont, a local village within Ramapo, defendants intentionally gerrymandered its borders to omit as many Orthodox Jews as possible. Id at 272. Ruling on the defendant's motion to dismiss, the LeBlancSternberg court held that the plaintiffs stated a claim under the Voting Rights Act. The court viewed the village boundaries as inhibiting the Orthodox Jewish residents from asserting their influence in Airmont. The court emphasized that in previous Ramapo elections, the plaintiffs, though a numerical minority, "would attempt to elect officials who would represent them on matters of local concern including zoning and taxation. Although plaintiffs still possess the right to vote, their right to 'fair and effective representation' on matters of local concern has allegedly been abridged through the deliberate and discriminatory minimization of their votes' effectiveness." Id at 272 (citations omitted).

Although the LeBlanc-Sternberg decision reaches its holding without a discussion of Gingles, it stands for principles implicit in influence dilution claims. See Illinois Legislative Redistricting Commission v LaPaille, 786 F Supp 704, 715 (N D Ill 1992).

so See, for example, McNeil v Springfield Park District, 851 F2d 937, 947 (7th Cir 1988) (requiring use of Gingles preconditions in vote dilution actions); Hastert $v$ State Board of Elections, 777 F Supp 634, 653-55 (N D Ill 1991) (holding that it was not yet appropriate to adopt the concept that the Voting Rights Act protects "minority influence districts").

31851 F2d at 947 .

32 Id.

33 Id. See also Hastert, 777 F Supp at 653 (holding determining "injury becomes a more elusive and subjective concept ${ }^{n}$ without a bright-line rule).

${ }^{34} 851$ F2d at 947 . One way of determining which $\S 2$ claims are nonfrivolous is to focus on creating majority-minority districts. As one court explained:

A rule of thumb has emerged in the cases that to give blacks a reasonable assurance of obtaining a majority of votes in a district the population of the district must be at 
Whether courts should entertain influence dilution claims depends on whether courts view such claims as warranted or "marginal." Examining the view that such claims are "marginal" seems most instructive, as it determines whether these claims have adequate legal footing.

\section{CRitique of Courts that ApPly Gingles Test to INFLUENCE DILUTION CLAIMS}

Courts that hold that $\S 2$ does not cover influence dilution claims needlessly limit the remedies available to counter discriminatory districting practices. First, these courts construe the purposes and objectives of the Voting Rights Act much too narrowly. Additionally, in an effort to limit the number of "marginal" claims they will have to hear, these courts use the Gingles test to sacrifice far too many cases that are deserving of $\S 2$ protection.

\section{A. Treating All § 2 Claims Alike}

Courts applying the Gingles test to influence dilution claims believe that the Supreme Court aimed only to ensure that majority-minority districts are created whenever possible. ${ }^{35}$ Given the Court's preference for majority-minority districts, this reading is understandable. In Gingles, the Court created a bright-line rule that required $\S 2$ plaintiffs challenging at-large districts to be "sufficiently large and geographically compact to constitute a majority in a single-member district." ${ }^{.36}$ In Growe, by extending the Gingles holding to cover single-member district challenges, the Court again stressed its interest in creating majority-minority districts whenever possible. ${ }^{37}$ The Court's rulings have driven home the notion that minority electoral success alone fulfills the goals of $\S 2$. And in practice, concentrating minority voters into single-member districts has dramatically increased the number of minority elected officials. ${ }^{38}$

least 65 percent black (50 percent plus 5 percent to reflect the lower average age of blacks and hence lower voting population, 5 percent to reflect a lower fraction of registered voters, and 5 percent to reflect a lower turnout) and the voting population at least 60 percent black.

Prosser v Elections Board, 793 F Supp 859, 869 (W D Wisc 1992), citing Ketchum v Byrne, 740 F2d 1398, 1415-16 (7th Cir 1984).

${ }^{35}$ McNeil, 851 F2d at 947; Hastert $v$ Board of Elections, 777 F Supp 634, 653 (N D Ill 1991).

${ }^{36}$ Gingles, 478 US at 50.

37. See Growe, $113 \mathrm{~S} \mathrm{Ct}$ at 1084.

3s Stephen A. Holmes, Civil Rights Group Disputes Election Analyses on Black Dis- 
However, both the Supreme Court's and § 2's perspectives on the nature of political participation embody more than a mere pull of the lever on election day. Indeed, $\S 2$ refers to open participation for minority voters in the "political processes leading to nomination or election" as well as the opportunity "to elect representatives of their choice. ${ }^{39}$ Thus, political participation includes lobbying and coalition building in the electoral process (as well as voting) to influence an electoral outcome when a majorityminority district cannot be drawn.

Additionally, the Supreme Court has recognized that influence in an election plays a role in minority political participation when minorities lack a numerical majority. In Chisom, the Supreme Court concluded that "[a]ny abridgement of the opportunity of members of a protected class to participate in the political process inevitably impairs their ability to influence the outcome of an election." "Political participation" involves more than merely voting. Minority voter influence in an election could occur at different phases of an election campaign (for example, acting as a sizable voting bloc during a primary election or as a coalition force during a campaign). As the Chisom Court emphasized, a small group of voters can influence the outcome of an election. ${ }^{41}$ Thus, the Court has recognized the importance of minority influence outside the majority-minority district context.

Furthermore, vote dilution and influence dilution are very much intertwined, often in the same case. For example, minority voters might still face vote dilution within the majority-minority district paradigm. A reapportionment plan might "pack" minority voters into single-member districts to prevent them from asserting influence in surrounding districts. Such "packing" occurs when the minority-preferred candidate in the majority-minority district receives excessively more votes than needed to carry the election. ${ }^{42}$ An influence district would serve to capture those excess votes to assert minority influence in another district.

tricts, NY Times A15 (Dec 1, 1994).

3942 USC \$ 1973(b).

40 Chisom, 501 US at 397 (emphasis added).

41 Id at $2365 \mathrm{n} 24$.

42 Eskridge and Frickey, Cases and Materials on Legislation at 127 (cited in note 6). 
B. "Marginal" Claims and Bright-Line Rules

Courts that apply the Gingles standard to influence dilution claims also seek to prevent "marginal" or unwarranted § 2 claims. As one court emphasized, the Gingles test prevented plaintiffs from "open[ing] a Pandora's box of marginal Voting Rights Act claims."

The fear of "marginal" \& 2 claims flooding the court system might be legitimate. After all, the Gingles test was created to prevent frivolous claims against at-large district plans. Its brightline rule kept vote dilution from "becom[ing] a more elusive and subjective concept." ${ }^{34}$ It might seem natural to extend such a test to all single-member district challenges as well.

However, the Supreme Court's differentiation between "ability to elect" and "ability to influence" claims suggests that influence dilution claims do not always present "marginal" \$ 2 claims. Like ordinary vote dilution claims, some influence dilution claims might be cognizable under $\S 2$. The Supreme Court's reluctance to announce a test for the marginality of "ability to influence" claims should not suggest that influence dilution claims always fall entirely outside of $\S 2$ 's protection. Rather, this void should intimate that courts need a test to determine which "ability to influence" claims warrant $\S 2$ protection.

In "ability to influence" claims, $\S 2$, as well as the Gingles disclaimer, requires that courts take into account characteristics relevant to influence districts. The Senate Report itself indicates that "[w]hile these enumerated factors will often be the most relevant ones, in some cases other factors will be indicative of the alleged dilution. ... [T] $]$ here is no requirement that any particular number of factors be proved, or that a majority of them point one way or the another. ${ }^{345}$ When addressing influence dilution claims, therefore, courts should consider factors indicating that minority influence warrants relief in the form of an influence district.

\section{THE RATIONALE FoR CREATING INFLUENCE DISTRICTS}

Allowing influence dilution claims under $\S 2$ would create the need for influence districts as a remedy. It therefore is appropriate to explore political issues surrounding influence districts to

\footnotetext{
*3 Hastert $v$ Board of Elections, 777 F Supp 634, 654 (N D II 1991).

44 Id at 653 .

45 Voting Rights Act Amendments of 1982, S Rep No $97-417$ at 29 (cited in note 13).
} 
determine their legitimacy under the VRA before distinguishing valid influence dilution claims from invalid ones.

\section{A. Influence Districts and Minority Participation in the Political Process}

The key to grasping the concept of influence districts lies in understanding what influence means in the political process. Political influence does not guarantee group dominance in local elections. Rather, it serves as a process of deliberating, persuading, and affecting an electoral outcome. ${ }^{46}$ For example, a person who simply casts one ballot in a general election controls only one vote and can no longer influence others. Yet a person who acts within a group from the early stages of the electoral process increases the group's political influence, bolstering this influence at a time when deliberation, persuasion, and collaboration remain attainable. The more influence a group can assert over candidates, the greater the likelihood that the group will elect the candidate of its choice or impact the policies of another.

Because reapportionment affects the political influence of minority voters, district boundaries often spur debate. As Justice John Marshall Harlan noted, "[I]t is not clear to me how a court would go about deciding whether an at-large system is to be preferred over a [single-member] district system. Under one system, Negroes have some influence in the election of all officers; under the other, minority groups have more influence in the selection of fewer officers." ${ }^{377}$ Congress responded to Justice Harlan's concerns by favoring stronger minority influence in fewer districts-that is, by encouraging majority-minority districts. ${ }^{48}$ As a result, minority groups in majority-minority districts typically elect minority candidates to office. ${ }^{49}$

\footnotetext{
46 The "totality of the circumstances" includes factors such as "the opportunity to participate in the slating of candidates" and the responsiveness of "representatives slated and elected ... to [the] minority's needs," suggesting the central importance of participation in pre- and postelection phases. Abrams, 63 NYU L Rev at 456 (cited in note 16), quoting Zimmer $v$ McKeithen, 485 F2d 1297 (5th Cir 1973).

${ }^{47}$ Allen v State Board of Elections, 393 US 544, 586 (1969) (Harlan concurring in part and dissenting in part). This was the first case in which the Supreme Court interpreted the VRA to apply to electoral structures.

43 See Gingles, 478 US at 50.

49 Notable exceptions, in which white candidates were repeatedly reelected in majority-minority districts, include former United States Representatives Lindy Boggs from the Second District of Louisiana and Peter Rodino, Jr., from the Tenth District of New Jersey. Carol M. Swain, Black Faces, Black Interests: The Representation of African Americans in Congress 170-89 (Harvard, 1993).
} 
In contrast, minority groups in nonminority districts often lack the ability to elect minority candidates. ${ }^{50}$ Nonetheless, minority groups can influence election results. A small minority group, for example, might assert its influence by alerting candidates of minority needs, acting as a swing vote, or joining with other groups within an electorate to form a stronger voting bloc. ${ }^{51}$ Influence districts seek to strengthen minority voting blocs for those minority groups that can secure a viable influence.

Many civil rights advocates doubt whether minority groups can wield substantial political influence in predominately white districts. First, it is argued that influence districts ignore the fact that whites often function as a monolithic voting group. ${ }^{52}$ White voters, it is advanced, remain reluctant to vote for minority candidates or for minority causes..$^{53}$ Thus, the argument goes, relying on white crossover voting to achieve minority interests seems likely to fail.

Indeed, the very creation of majority-minority districts is premised on reversing the discriminatory practices endured by minority voters in predominately white districts as a result of bloc voting by the white majority. As one author notes, "[t]he idea that a racial minority in a polarized district electorate has influence or clout is simply inconsistent with the very definition of minority vote dilution. ${ }^{m 54}$ Therefore, it is argued, influence dis-

so Notable exceptions, in which minorities have recently been elected in majority white districts, include Senator Carol Moseley Braun (III), former Governor L. Douglas Wilder (Va), Congressmen Gary Franks (Conn) and J.C. Watts (Okla), Seattle Mayor Norm Rice, Minneapolis Mayor Sharon Sayles Belton, and Dallas Mayor Ron Kirk.

51 With the swing vote, the minority voting bloc carries a huge amount of influence in electoral outcomes. One need only examine the Knesset, Israel's parliament, to appreciate this point. Shas, a party of Sephardic Orthodox Jews, is numerically a small minority in the Knesset. However, because the two main parties rarely agree or coalesce, both groups placate Shas's interests to gain a majority of votes. See Kenneth L. Cohen, Direct Election of Prime Minister, Jerusalem Post (Jul 13, 1991); Ohad Gozani, Compromise Hope for Israeli Budget, Daily Telegraph I9 (Jan 2, 1992).

52 See Lani Guinier, The Representation of Minority Interests: The Question of SingleMember Districts, 14 Cardozo L Rev 1135, 1166-67 (1993). Although several civil rights advocates criticize influence districts, Professor Guinier's criticisms have received the most attention, in part due to the scrutiny placed on her writings when President Clinton nominated her to head the Civil Rights Division of the Department of Justice. See also Abrams, 63 NYU L Rev at 493-95 (cited in note 16).

53 Sushma Soni, Defining the Minority-Preferred Candidate Under Section 2, 99 Yale L J 1651, 1656 n 24 (1990), citing Gingles, 478 US at 54, 59 for this contention. In Gingles, Justice Brennan noted that white voters remain "extremely reluctant" to vote for black candidates. 478 US at 54. See also Professor Guinier, 14 Cardozo L Rev at 1166 (arguing that a racial minority has no influence in an electorate with racially polarized voting).

54 Guinier, 14 Cardozo L Rev at 1166, 1166-67 n 98. This distrust in white voters' 
tricts set minority groups up for defeat and political isolation within an electorate. Creating influence districts simply revives past discrimination.

Second, it is argued that unlike the majority-minority district paradigm, no "benchmark" can define political influence. ${ }^{55}$ As a consequence, courts would have no guidelines to determine when a small minority group can assert influence. The resulting caseby-case appraisals would place too much discretion in the hands of judges and would result in inconsistent outcomes. Thus, plaintiffs would not receive uniform treatment by courts.

Contrary to these arguments, minority candidates in nonminority districts made substantial electoral gains in the 1992 elections. Increasingly, minority candidates have successfully relied on white crossover voting to win local and national offices. ${ }^{56}$ Moreover, in some nonminority districts, white candidates have had to enlist minority support to ensure victory. ${ }^{57}$ This trend demonstrates that minority voters can wield political clout without constituting the majority of a district. ${ }^{58}$

Influence districts also encourage interracial coalitions and alert candidates to the needs and interests of minority groups. ${ }^{59}$ If an influence district elects a minority candidate, a mobilization of cross-racial voters has succeeded. And, if a district elects a nonminority candidate, the elected official remains accountable to the interracial voting block's interests. ${ }^{60}$

willingness to respect minority concerns has also been expressed in plainer terms: "We didn't have much respect for influence districts. We thought that was a misnomer, really, a kind of phantom that does not yield real political influence or build political power in the state." Nelson Rivers, President of the South Carolina Chapter of the NAACP, quoted in Burton $v$ Sheheen, 793 F Supp 1329, 1355 n 47 (D SC 1992).

55 See Allan J. Lichtman and J. Gerald Hebert, A General Theory of Vote Dilution, 6 La Raza L J 1, 16 (1993).

56 See note 50.

57 See Swain, Black Faces, Black Interests at 145-69 (cited in note 49). The Sixth District of South Carolina has never had a black representative. And for most of their years there, blacks have felt little effective representation from their elected Congressional representative. By 1982, the district, though 40 percent black, felt even more ignored when Republican John Napier decidedly abandoned any efforts to reach out to blacks and working-class whites, preferring instead to run with the support of the affluent Myrtle Beach homeowners. Id at 148-50. Robin Tallon, who operated a chain of men's clothing stores, decided to run against Napier, recognizing that minority voices went unheard. With the support of black voters plus 14 percent of the white voters, he defeated Napier by an 8 percent margin. Id at 151 . See also note 60 .

5s See J. Morgan Kousser, Beyond Gingles: Influence Districts and the Pragmatic Tradition in Voting Rights Law, 27 USF L Rev 551, 553-54 (1993).

59 Id at 587.

60 For example, during the 1980s, Florida's Eighteenth Congressional District steadily became a majority Hispanic district due to the influx of Cuban immigrants. Although 
Alan Wheat's electoral success from 1982 to 1992 in the Fifth Congressional District of Missouri shows how an influence district might work. Blacks constituted 20 percent of the district's population. ${ }^{61}$ So, Wheat worked to build a biracial coalition by listening to voter concerns and placing those concerns at the fore of his campaign. He participated in events sponsored by both minority and majority groups and encouraged them to do the same. ${ }^{2}$ Though Wheat mustered less than half of the white votes in his 1982 bid, his backing by black voters ( 20 percent) plus 38 percent from white voters gave him a 58 percent to 40 percent victory over his opponent. ${ }^{63}$ His subsequent victories have been by an increasing margin due to Wheat's strong leadership and attentiveness to his district's needs. ${ }^{64}$

In the same way that blacks were were able to participate in a successful biracial coalition, minority groups in influence districts can exert pressure on office holders to heed their concerns. Influence districts give minority voters in nonminority districts the power to impact elections.

\section{B. The Racial Implications of Drawing Influence Districts}

1. The legitimacy of race-conscious districting.

Creating influence districts, like creating majority-minority districting schemes, emphasizes the significance of race in electoral reapportionment planning. It is clear that race-conscious districting has served to redress past discrimination against minority voters. Whether race should continue to play a significant role in the reapportionment process, however, remains hotly contested.

\footnotetext{
the district's representative, Claude Pepper, was white, only once did he face significant opposition from a Cuban-American candidate because Pepper became a strong advocate of the anti-Castro cause and a supporter of refugee status for all Cubans. Rodolfo $O$. de la Garza and Louis DeSipio, Save the Baby, Change the Bathwater, and Scrub the Tub: Latino Electoral Participation After Seventeen Years of Voting Rights Act Coverage, 71 Tex L Rev 1479, 1520 n 268 (1993).

61 See Swain, Black Faces, Black Interests at 118-19 (cited in note 49).

62 Id at 124.

$\infty$ Id.

${ }^{64}$ Id. In October, 1994, Wheat decided to run for U.S. Senate and lost. One might also look to Dallas Mayor Ron Kirk's recent election, in which he captured 97 percent of the black vote, 42 percent of the white vote, and 14 percent of the Hispanic vote to win the race. Steve McGonigle, Voters cross racial lines to elect Kirk, Dallas Morning News 11A (May 8, 1995).
} 
One argument against race-conscious districting is that it defeats the civil rights movement's goal of a color-blind society that looks past racial differences. ${ }^{65}$ The civil rights movement sought to de-emphasize the significance of race and encourage nonracial solutions to past problems. The color-blind, or raceneutral, baseline avoids suspicions of intentional racial discrimination. Color-blind districting, the argument goes, encourages voters to look beyond race and focus on common political goals. ${ }^{66}$

One might also view race-conscious districting as a quota system for minority voters. ${ }^{67}$ When district lines are allowed to be drawn in a race-conscious fashion, minority groups receive an "entitlement" solely based on race. Such "entitlements" allow typecasting, stigmatizing, and subjugation of minorities to persist. $^{68}$ A color-blind approach, in contrast, invites all racial groups to look beyond political power based on race and to avoid stigmatizing some sectors in society as oppressors and others as members of an underclass. ${ }^{69}$

However, it is clear that the vestiges of past discrimination persist, making some form of racial safeguards necessary. Simply put, "[t]o pretend to draw color-blind boundaries becomes, at best, a charade, and at worst, a cloak for discrimination, given the correlation between race and other demographic factors such as education, income, and urban versus suburban residence."70 To suggest that districting should (or could) occur in a "race-neutral vacuum" denies the history of segregation in America. A race-conscious districting scheme recognizes the effects of past discrimination and serves to strengthen the political clout of its victims.

More importantly, two recent Supreme Court cases demonstrate that race may still be legitimately used in the districting process. In Voinovich $v$ Quilter ${ }^{71}$ white Democrats challenged Ohio's reapportionment plan. Because the plan created several majority-minority districts, the white plaintiffs argued that the

65 Morris B. Abram, Affirmative Action: Fair Shakers and Social Engineers, 99 Harv L Rev 1312, 1312 (1986). See also Lani Guinier, The Triumph of Tokenism: The Voting Rights Act and the Theory of Black Electoral Success, 89 Mich L Rev 1077, 1091-1101 (1991).

${ }^{66}$ See Guinier, 89 Mich L Rev at 1081-1101.

${ }^{67}$ See Abram, 99 Harv L Rev at 1314-20 (arguing that results-based affirmative action is, essentially, a quota system).

${ }^{6 s}$ See id at $1322-23$.

69 See id at 1322-26.

${ }^{70}$ Lichtman and Hebert, $6 \mathrm{La}$ Raza L J at 22 (cited in note 55).

7113 S Ct 1149. 
plan "packed" minority voters into too few districts, minimizing minority influence in the other electoral districts. ${ }^{72}$ Nonetheless, the Court held that $\S 2$ of the VRA did not contain a per se prohibition against creating majority-minority districts. ${ }^{73}$ Rather, the Court recognized the importance of providing minority voters with tangible voting results through the use of such districting. ${ }^{74}$

In Shaw $v$ Reno, ${ }^{75}$ the Court identified an inappropriate use of race in a districting plan, but by implication upheld the use of race in other contexts. When North Carolina obtained one additional congressional seat as a result of the 1990 census, the state legislature created two majority-minority districts to reflect the state's 20 percent African American population. The districts, however, were oddly drawn. ${ }^{76}$ The plan was so bizarre on its face that it was "unexplainable on grounds other than race." Accordingly, the Court reversed the district court's decision. ${ }^{78}$ The Court reasoned that some race-based districting efforts demand close judicial scrutiny because of the potential for racial gerrymandering to balkanize society. ${ }^{79}$ The Court's scrutiny of the North Carolina legislative plan revealed that the plan violated the Equal Protection Clause of the Fourteenth Amendment because it disregarded traditional districting principles such as geographic compactness, contiguity, and respect for political subdivisions. ${ }^{80}$

Despite its holding, the Shaw Court did not prohibit raceconscious districting per se. First, the Shaw Court focused on District 12's "highly irregular" shape. Thus, under a narrow reading, it would appear that "regular-shaped" districts do not raise

72 Id at 1153.

73 Id at $\mathbf{1 1 5 6 .}$

74 Id. Quilter is discussed further at text accompanying notes 19-23.

75113 S Ct 2816 (1993).

${ }^{76}$ Id at 2819-20. District 1 was centered in the northeast portion of North Carolina and, "with finger-like extensions, it reache[d] far into the southern-most part of the State near the South Carolina border." Id at 2820. District 12 wound in "snake-like fashion through tobacco country, financial centers, and manufacturing areas "until it gobble[d] in enough enclaves of black neighborhoods." Id at 2821, quoting Shaw v Burr, 808 F Supp 461, 476-77 (E D NC 1992), rev'd, Shaw v Reno, 113 S Ct 2816.

7h Shaw, $113 \mathrm{~S} \mathrm{Ct}$ at 2825, quoting Arlington Heights v Metropolitan Housing Development Corp., 429 US 252, 266 (1977).

${ }_{78}$ See Shaw, $808 \mathrm{~F}$ Supp at 461 (holding both that the VRA was not facially unconstitutional to the extent that it permitted a plan providing for black majorities in certain districts, and that the VRA was not unconstitutional as applied by the North Carolina legislature in adopting a plan with such districts).

79 Shaw, 113 S Ct at 2832.

8o Id at 2826-28. 
similar constitutional concerns. ${ }^{81}$ Second, the Court's analysis builds on precedents establishing that intentional race-conscious districting is not inherently unconstitutional. ${ }^{82}$ Third, the Court indicated that race-conscious districting is not per se problematic or a trigger for strict judicial scrutiny. It emphasized that "redistricting differs from other kinds of state decision making in that the legislature always is aware of race when it draws district lines, just as it is aware of age, economic status, religious and political persuasion, and a variety of other demographic factors. That sort of race consciousness does not lead inevitably to impermissible race discrimination. ${ }^{283}$ The Court's decision in Quilter, decided in the same term as Shaw, supports the conclusion that Shaw is not a broad attack on race-conscious districting per se. ${ }^{84}$

2. Differentiating between race-conscious districting and monolithic voters.

An implicit argument against race-conscious districting deserves special attention. Arguably, grouping people together into political units based solely on race treats racial minorities as one monolithic group without differing goals, beliefs, ideologies, and lifestyles. Arguably, race-conscious districting subordinates intragroup diversity.

However, race-conscious districting should not merit that conclusion. Some minority voters support minority candidates even if the candidate's position on substantive issues differs from theirs because of the symbolic value of electing a person of a particular race. ${ }^{85}$ At the grass-roots level, the election of minori-

${ }^{81}$ See Richard H. Pildes and Richard G. Niemi, Expressive Harms, "Bizarre Districts," and Voting Rights: Evaluating Election-District Appearances After Shaw v. Reno, 92 Mich I $\operatorname{Rev} 483,495$ (1993). Under a broader reading, one could interpret Shaw as casting the validity of all race-based districting into doubt. However, an in-depth analysis of the constitutionality of race-based districting lies beyond the scope of this Comment. For purposes of this Comment, the continued constitutionality of race-based districting is presumed.

52 Id at 495-96, 496 in 60 (pointing to the Shaw Court's reliance on United Jewish Organizations $v$ Carey, 430 US 144, 161 (1977), which held that "neither the Fourteenth nor the Fifteenth Amendment mandates any per se rule against using racial factors in districting and apportionment.").

\& Pildes and Niemi, 92 Mich I Rev at 496, 496 n 61, quoting Shaw, 113 S Ct at 2826. See also Hays $v$ Louisiana, 839 F Supp 1188, 1191 (W D La (1993), vacated on other grounds, 114 S Ct 2731 (1994) (holding that race-conscious districting was permissible under Shaw).

84 Pildes and Niemi, 92 Mich L Rev at 496-98.

85 See Abrams, 63 NYU L Rev at 496 (cited in note 16). See also Swain, Black Faces, Black Interests at 5 (cited in note 49 ). 
ty officials has been crucial in building political morale in minority voters. Because minority voters see that there is someone in the government who will respond to their interests, they begin to believe that the government will be more open to their preferences and ideas. Minority voters often feel more at ease when represented by minority officeholders because of the message projected: that minority concerns are being addressed and that minority interests are being protected. $^{86}$ Thus, minority voters might be more willing to entrust a minority candidate with their votes. ${ }^{87}$ Yet both minority and nonminority candidates can defeat this tendency by reflecting the interests of individual minority voters.

\section{Proposed Standard For Determining When aN INFLUENCE DILUTION CLAIM IS COGNIZABLE UNDER $§ 2$ OF THE VOTING RIGHTS ACT}

Currently, lower courts lack an appropriate standard for determining which influence dilution claims are cognizable under the VRA. On the one hand, using the Gingles test forces courts systematically to reject influence dilution claims because plaintiffs fail to meet the first prong of the test. Conversely, the fact that no other standard has been recognized by the Supreme Court encourages courts to treat all influence dilution claims as "marginal" \& 2 claims. ${ }^{88}$

Courts need new guidelines to determine which influence dilution claims are cognizable under $\S 2$. Admittedly, such a test will be artificial to some degree because of the subjective nature of political influence. Unlike the majority-minority district threshold, influence districts might arise in various ways. For example, a minority group might be recognized as constituting an influence district by either commanding a large portion of one political party (thereby affording the group political clout in prima-

${ }^{86}$ Guinier, 14 Cardozo L Rev at 1147 (cited in note 52). See also Katherine Tate, From Protest to Politics: The New Black Voters in American Elections 21-49, 164-165 (Harvard, 1993) (discussing the overwhelming significance of race to black voters).

${ }^{67}$ The debate over symbolic representation came to light in the battle over Justice Clarence Thomas's nomination to the Supreme Court by President George Bush in 1991. Although many civil rights groups opposed the nomination, some members of the civil rights community endorsed Thomas solely because he was black. To many blacks, a black presence on the Supreme Court served as a barometer of black progress since slavery. Tate, From Protest to Politics at 170. Moreover, such supporters expressed a hope that Justice Thomas's conservative views would soften over time. Id. See also id at 29-45 (discussing conservatism in the black electorate).

${ }^{83}$ See, for example, McNeil, 851 F2d at 947. 
ry elections) or carrying the swing vote when other dominant parties are evenly split (thereby affording the group tie-breaking votes). In short, no numerical standard can serve to determine which influence dilution claims should pass muster.

However, some standard can be created to advance the goals of the VRA. The optimal standard for determining which influence dilution claims are cognizable should manifest factors that allow for case-by-case determinations. That way, $\$ 2$ can accommodate warranted influence dilution claims while preventing frivolous claims from reaching the "totality of circumstances" inquiry. The standard should also embody certain voting characteristics of the entire minority voting age population in the United States. Such characteristics should account for minority voter turnout, crossover voting, and proportional gains made by minority candidates and minority-preferred candidates. Finally, the standard should be applicable to influence dilution claims on the federal, state, and local levels. Such a standard would recognize that small groups of minority voters face similar dynamics in district elections, yet would accommodate local variances.

\section{A. The Proposed Test}

This Comment proposes a three-part test for determining which influence dilution claims warrant $\S 2$ protection. Under this proposal, courts should first examine the minority group's cohesiveness. Second, courts should scrutinize the "geographic compactness" of the proposed influence district. Lastly, courts should assess the potential for interracial coalitions, crossover voting, and/or a minority swing vote. As an additional factor, courts should ensure that proposed influence districts do not disturb majority-minority districts. Once plaintiffs establish all three requirements and fulfill the additional proviso regarding majority-minority districts, courts may proceed to the "totality of circumstances" inquiry under $\S 2$.

\section{The factors analyzed.}

Under the first prong of the proposed test, courts should examine the minority group's political cohesiveness. Just as the Gingles Court viewed this factor as crucial in determining a minority group's potential to elect its preferred candidate, political cohesiveness serves as a vital indicator of a minority group's 
ability to influence election outcomes. ${ }^{89}$ One way of determining political cohesiveness is to examine the socioeconomic similarities of the claimants. ${ }^{90}$ Minority voters in similar socioeconomic conditions tend to have similar interests and concerns and vote accordingly. ${ }^{91}$ Past voting practices are another indicator of political cohesiveness among minority voters. Establishing that a significant percentage of a minority group usually votes for the same candidate is, after all, one way of defining a voting bloc. ${ }^{92}$

Second, courts should examine the "geographic compactness" of the proposed influence district's boundaries. The Supreme Court has indicated that a "bizarrely-shaped" districting plan that "rationally cannot be understood as anything other than an effort to separate voters into different districts on the basis of race... [without] sufficient justification" potentially violates the Equal Protection Clause. ${ }^{93}$ Thus, if plaintiffs are proposing an unusually shaped district, they must present evidence that the contested district boundaries dilute minority voting strength. If a court can conclude as a preliminary matter that the shape of the proposed district redresses a dilutive voting scheme, the boundaries should pass muster. A court might examine former district boundaries to determine whether the challenged boundaries dilute a minority bloc's strength. ${ }^{94}$

Third, courts should assess the potential for interracial coalitions, crossover voting, and/or a minority swing vote. Although minority voters in influence districts cannot control the outcome of an election, they might manifest their influence by either working with other members of the electorate, relying on voter dissatisfaction with major candidates, or carrying the swing vote. Minority plaintiffs may be able to establish, for example, that

Gingles, 478 US at 51.

90 These factors import views expressed in $\S 2$, in the Senate Factors, and by the Supreme Court in vote dilution cases. They also include situations in which minority candidates have mounted successful campaigns. See also Kousser, 27 USF L Rev at 576 (cited in note 58).

${ }^{91}$ See Swain, Black Faces, Black Interests at 7-11 (cited in note 49). Socioeconomic similarities serve as an illustrative, rather than dispositive test. Indeed, Swain acknowledges that the rising number of African American families earning over $\$ 50,000$ per year complicates her analysis. Still, the argument has force in segregated urban areas that are quartered off into suburban districts. See also Tate, From Protest to Politics at 25-29 (cited in note 86) (discussing the effect of class stratification on African American racial identities).

${ }_{52}$ Gingles, 478 US at 56.

${ }^{93}$ See Shaw, $113 \mathrm{~S} \mathrm{Ct}$ at 2828.

${ }^{94}$ This determination would not be difficult to assess given the extent to which courts face this issue using the Gingles test. 
they work effectively with other members of the electorate by demonstrating that their interests mesh with nonminority group interests enough either to form interracial coalitions or to demonstrate that white voters would vote for the minority-preferred candidate. In the swing vote paradigm, the minority group wields heavy influence because two major opposing political parties are evenly divided and neither is capable of winning without a significant number of votes from the minority group. Accordingly, to satisfy the third prong, minority plaintiffs must demonstrate the potential power of their influence in either primary or general elections.

The test's additional proviso requires courts to ensure that the proposed influence district does not serve to dismantle existing or attainable majority-minority districts. Indeed, the Supreme Court has shown a preference for majority-minority districts when attainable. It created the Gingles threshold test to enable minority voters to elect their preferred candidates in situations in which "a bloc-voting majority [is] usually [ ] able to defeat candidates supported by a politically cohesive, geographically insular minority group." ${ }^{955}$ Accordingly, courts determining influence dilution claims should protect any of the rights of minority voters in majority-minority districts before proceeding to create influence districts.

This proposed test would help courts better fulfill the goals of the VRA by alleviating some of the abuses in the majority-minority district system. For example, an influence dilution claim might aim to create an influence district out of a "packed" majority-minority district. ${ }^{96}$ Such districts "waste" minority votes by creating lopsided victories and preventing minority influence in other districts-particularly where a small minority community also exists in a neighboring district. Such influence dilution claims should be eligible for relief so long as the majority-minority district remains intact and the newly-designed influence district passes muster. Therefore, if minority voters sought to create an influence district out of a "packed" majority-minority district's "wasted" votes, the majority-minority district would still have to have minorities make up over 60 percent of its voting age population. This preserves the integrity of majority-minority districts while expanding the rights of minority voters in accordance with the VRA. ${ }^{97}$

95 Gingles, 478 US at 48-49.

96 See, for example, Prosser $v$ Elections Board, 793 F Supp 859, 869 (W D Wisc 1992).

97 Determining what constitutes a "packed" district raises many issues beyond the 
2. Rationale for the test.

Several reasons justify case-by-case determinations in dealing with influence dilution claims. First, quantifying political influence presents impracticalities. Because influence differs from district to district, a bright-line standard would unduly prevent some smaller minority groups from asserting their voting rights-particularly in the swing vote scenario. The proposed standard promotes a review of all factors relevant to influence districts. Such a review accounts for a given district's political dynamics.

Second, the proposed standard satisfies judicial efficiency concerns. Courts already have a familiarity with the political cohesiveness and geographic compactness factors. The third factor (interracial coalitions, crossover voting, and/or the minority swing vote) presents the only new concept. However, because plaintiffs have the burden of establishing this factor, courts would simply examine the evidence presented to determine an influence dilution claim's plausibility.

Third, the proposed test serves as a useful tool in dealing with influence districts created out of combinations of distinct minority groups. ${ }^{98}$ Often, various minority groups have similar goals and act in a politically cohesive manner. In Campos v City of Baytown, Texas, for example, Hispanic and African American citizens of Baytown, Texas, successfully challenged that city's atlarge districting plan under $\S 2$ by demonstrating that together they composed a majority in a single-member district. ${ }^{99}$ In such challenges under the influence district paradigm, courts should allow the various minority groups to decide among themselves what political course they could best sail. Allowing distinct minority groups to achieve political gains via interracial coalition building certainly fulfills the vision of the VRA. ${ }^{100}$

scope of this Comment. However, the simple fact remains that determining when "packing" has occurred stirs the debate over majority-minority districting. One commentator has argued that the Ketchum 60 percent rule in forming majority-minority districts has no empirical validity. Kousser, 27 USF L Rev at 565-68 (cited in note 58).

${ }_{98}$ See, for example, DeBaca v County of San Diego, 794 F Supp 990 (S D Cal 1992), aff'd, DeBaca $v$ County of San Diego, 5 F3d 535 (9th Cir 1993). DeBaca involved a $\$ 2$ claim brought by a coalition of African Americans, Hispanics, and Asian Americans. The court rejected this "aggregated" claim because plaintiffs failed to demonstrate the existence of racially polarized voting. Id at 997, 1000. This Comment assumes the permissibility of such claims.

s9 840 F2d 1240, 1244 (5th Cir 1988).

100 For example, in devising a reapportionment plan for New York City in 1990, the New York City Districting Commission asked minority groups that were not large enough 
Case-by-case analysis provides a good way to balance the interests of the distinct minority groups competing for influence districts. If, for example, courts applied a bright-line threshold rule for influence dilution claims that two competing minority groups both established, they would still face a difficult districting problem. By using the factors articulated above, courts can determine which groups would best act in coalition with other voters or, alternatively, mediate boundaries between the groups.

B. Testing the Test

\section{Clear applications.}

In Armour, the court concluded that the Gingles test could not apply in influence dilution claims because the test entailed a Supreme Court attack only upon at-large districting schemes. ${ }^{101}$ If a court were analyzing Armour under the proposed test, it would not apply the Gingles preconditions. Instead, it would first assess the minority group's political cohesiveness. The Armour plaintiffs evidenced a strong sense of political cohesiveness by their past voting patterns and similar political preferences. Indeed, the minority acted as a strong voting bloc and demonstrated socioeconomic similarities. ${ }^{102}$

Second, a court must examine the plaintiff s' geographic compactness. The Armour court noted that the apportionment between Districts 52 and 53 divided a geographically compact minority group between two single-member districts. ${ }^{103}$ Because the plaintiffs' proposed plan removed this dilution, their plan would likely pass muster under the influence district paradigm.

Third, a court would scrutinize the minority group's ability to build interracial coalitions, command crossover votes, and/or car-

\footnotetext{
to form majority-minority districts whether they preferred being grouped with another minority group to form a majority-minority district or being grouped with nonminorities. The preferences of minority groups varied. For example, while the Hispanic community in one part of the city preferred being combined with another minority group to form a "multi-ethnic" district, there was a lack of consensus among Asian Americans in that same area over whether to form a "multi-ethnic" district, or an "influence" district which would align them with the white community. Frank J. Macchiarola and Joseph G. Diaz, The 1990 New York City Districting Commission: Renewed Opportunity for Participation in Local Government or Race-Based Gerrymandering?, 14 Cardozo L Rev 1175, 1225-28, 1226 n 233 (1993).

101775 F Supp at 1051.

102 Id at $1057-58,1055-56$.

103 Id at 1052.
} 
ry a swing vote. Although the minority plaintiffs in Armour did not have a swing vote, they did play a significant role in local Democratic politics. In their proposed reconfigured district, the minority group constituted around 50 percent of the usual Democratic vote, enough to force any Democratic candidate to be sensitive to their views. ${ }^{104}$

Additionally, a court must ensure that the proposed influence district did not disturb surrounding majority-minority districts. The Armour plaintiffs would satisfy the condition because their proposed influence district sought to combine minority voters from two nonminority districts. Because the Armour plaintiffs would fulfil each of the proposed test's necessary factors, their claim would proceed to the "totality of circumstances" analysis.

Hastert $v$ Board of Elections provides a second clear example of how the proposed standard would work. African American plaintiffs in Hastert asserted that a congressional reapportionment plan diluted minority voting strength in Springfield and Decatur, Mlinois. ${ }^{105}$ The plaintiffs proposed a separate plan that joined the two cities as an influence district. That way, African Americans would constitute 4.7 percent of the district's voting population. ${ }^{106}$

Under the first prong of the proposed test, a court might infer that, because the Hastert plaintiffs devised a plan to combine their cities, they fulfilled the cohesiveness requirement. However, the Hastert court found that the minority plaintiffs failed to present any evidence of political cohesiveness. ${ }^{107}$ Perhaps the minority plaintiffs could have provided evidence of their socioeconomic similarity, similar political leanings, or similar political interests to satisfy the court's standard.

The compactness prong of the proposed test involves demonstrating the current district boundary's dilutive effect. The Hastert plaintiffs presented evidence of the proposed boundary's effect on African American voters, but provided no context for this conclusion. For example, they did not establish that their proposed plan redressed problems in the previous reapportionment plan, which placed the two cities in separate districts. ${ }^{108}$

104 Id at 1059-60.

105777 F Supp at 651.

106 Id at 651 .

107 Id at 655.

199 The Hastert court noted that the plaintiffs "also failed to offer specific evidence proving that any of the 'typical objective factors' associated with minority vote dilution are at work in both the Springfield and Decatur communities." Id. 
In addition, whether Springfield and Decatur are geographically compact remained uncertain. Even though approximately thirtyfive miles and six townships separate Springfield and Decatur at their closest township boundaries, ${ }^{109}$ it is unclear whether Shaw would invalidate such a scheme.

Third, none of the evidence presented by the Hastert plaintiffs suggested that any of the possibilities required by the test's third prong would occur. Indeed, forming a 4.7 percent minority influence district amounts to continued dilution if the majority population would not pay much attention to the minority voters.

Finally, it is unclear whether the proposed influence district would affect any majority-minority districts. Thus, because the Hastert plaintiffs would insufficiently allege influence dilution under the test proposed in this Comment, their plan to create an influence district should fail.

\section{A harder application.}

The proposed test supports the creation of influence districts to remedy "packing" in majority-minority districts. Determining when "packing" has occurred necessarily becomes the difficult inquiry. ${ }^{110}$

Accepting the rule in Ketchum $v$ Byrne helps solve this dilemma. ${ }^{11}$ This "rule of thumb" looks for at least a 60 percent minority voting age population to form a majority-minority district. Accordingly, the proposed test would allow the minorities in excess of the 60 percent required for a majority-minority district to maintain an influence dilution claim under $\S 2$ if they meet the other conditions set out above. Where the additional percentage of minority voters cannot demonstrate the three requirements, however, their case should not go forward.

In Prosser $v$ Elections Board, an African American Assembly Representative reported that although her district was 74 percent black, blacks cast only one hundred more votes than whites. ${ }^{112}$ Assuming that the extra 14 percent of minorities in the district sought to create an influence district, their burden of

\footnotetext{
109 Id at $651 \mathrm{n} 29$.

110 For further discussion of the problems of "packing," see generally, Parker, Racial Gerrymandering and Legislative Reapportionment, in Chandler Davidson, ed, Majority Vote Dilution (Howard, 1984).

11140 F2d 1378, 1415 (7th Cir 1984). The circuit court in McNeil and district court in Prosser have approved of the Ketchum test in reapportionment cases. See McNeil, 851 F2d at 945; Prosser v Elections Board, 793 F Supp 859, 869 (W D Wis 1992).

112793 F Supp at 870 .
} 
proof under the third prong would be elevated because of poor voter turnout. More facts would be needed to determine whether the swing vote, crossover voting, or interracial coalition paradigm would come into effect. From the facts presented, however, none of these factors seemed to be present. Still, if one of these factors were present, the minority plaintiffs might be allowed to bring suit. The first two prongs of the test would require more straightforward analysis by courts. ${ }^{113}$

\section{CONCLUSION}

Recognizing influence dilution claims under $\S 2$ of the Voting Rights Act strengthens minority votes and minority voters' rights. Influence dilution claims do not represent "marginal" vote dilution claims per se. Rather, such claims belong to the family of other vote dilution claims under $\S 2$. Like other $\S 2$ claims, some influence dilution claims should not go on to the "totality of circumstances" inquiry. However, the Gingles test does not and should not govern "ability to influence" claims.

Courts, therefore, should consider applying the proposed standard to determine which "ability to influence" claims warrant $\S 2$ protection. The proposed test-which looks to political cohesiveness, geographic compactness, and potential for interracial coalitions, crossover voting, and a swing vote-embodies characteristics of influence districts rather than majority-minority districts. This test recognizes that while large and small groups of minority voters have different needs, both groups share the same rights. Recognizing influence dilution claims would protect small groups of minority voters. And indeed, that objective fulfills the vision of the Voting Rights Act.

113 The first two prongs need not be spelled out here because they require the same analysis used in the Gingles test. 


\section{,}

